\title{
Viral hepatitis B and C in HIV-exposed South African infants
}

Cynthia Tamandjou Tchuem ${ }^{1 *}$, Mark Fredric Cotton ${ }^{2}$, Etienne Nel ${ }^{3}$, Richard Tedder ${ }^{4}$, Wolfgang Preiser ${ }^{1}$, Avy Violari ${ }^{5}$, Raziya Bobat ${ }^{6}$, Laura Hovind ${ }^{7}$, Lisa Aaron ${ }^{8}$, Grace Montepiedra ${ }^{8}$, Charles Mitchell ${ }^{9}$ and

Monique Ingrid Andersson ${ }^{1,10}$

\begin{abstract}
Background: Whilst much attention is given to eliminating HIV mother-to-child transmission (MTCT), little has been done to ensure the same for hepatitis B virus (HBV) transmission. The introduction of HBV immunization at six weeks of age has reduced HBV horizontal transmission in South Africa. However, in order to eliminate HBV MTCT, further interventions are needed. The risk of hepatitis C virus (HCV) MTCT in HIV-infected (HIV+) African women is not yet well described. This study aimed to determine the rate of HBV and HCV vertical transmission in HIV-exposed infants in South Africa.

Methods: Serum samples from infants enrolled in an isoniazid prevention study (P1041) were screened for HBV and HCV serology markers; screening was performed on samples collected at approximately 60 weeks of age of the infants. HBV DNA was quantified in HBsAg positive samples and HBV strains characterized through gene sequencing. All HCV antibody samples with inconclusive results underwent molecular testing.

Results: Three of 821 infants were positive for both HBsAg and HBV DNA. All HBV strains belonged to HBV subgenotype A1. The rtM204I mutation associated with lamivudine resistance was identified in one infant, a second infant harboured the double A1762T/G1764A BCP mutation. Phylogenetic analysis showed clustering between mother and infant viral genomic sequences. Twenty-one of 821 HIV-exposed infants tested had inconclusive HCV antibody results, none were HCV PCR positive.

Conclusions: This study suggests that HBV vertical transmission is likely to be occurring in HIV-exposed infants in South Africa.. A more robust strategy of HBV prevention, including birth dose vaccination, is required to eradicate HBV MTCT. HCV infection was not detected.
\end{abstract}

Keywords: Hepatitis B virus, HIV, Hepatitis C virus, Infants, South Africa

\section{Background}

Persistent viral hepatitis is a major public health problem and a major cause of infectious disease mortality, similar to HIV, malaria and tuberculosis [1]. Globally, hepatitis B (HBV) and hepatitis C (HCV) viruses affect an estimated 257 million and 71 million individuals,

\footnotetext{
* Correspondence: craissat@gmail.com

'Division of Medical Virology, Department of Pathology, Faculty of Medicine and Health Sciences, Stellenbosch University, Cape Town, South Africa Full list of author information is available at the end of the article
}

respectively. Sub-Saharan Africa (SSA), where the prevalence of chronic HBV infection is estimated at over $8 \%$, and the Western Pacific region bear the greatest burden of HBV whilst HCV prevalence is highest in North Africa $[2,3]$.

Early regional studies in SSA described high HBV surface antigen ( $\mathrm{HBsAg}$ ) prevalence rates in children older than one year but low rates in infancy, implicating horizontal transmission at or after the neonatal period as the major route of transmission $[4,5]$. These data informed 
the current policy of routine infant immunisation commencing at six weeks of age in many sub-Saharan African countries. Although this strategy led to a decrease in HBV infection in children [6], infants are still infected during the perinatal period [7]. HBV acquired during childhood carries a high risk for persistent infection and consequent severe liver disease. World Health Organization (WHO) guidelines recommend that the first dose of $\mathrm{HBV}$ vaccine be given shortly after delivery [8]; this is especially important in highly endemic regions such as SSA and the Western Pacific, where HBV mother-to-child transmission (MTCT) and early childhood transmission predominate. While implementation of this practice in the Western Pacific region has reduced both HBV MTCT and early childhood infections [9], HBV MTCT remains a concern in SSA [7]. Although current data suggest that immunisation starting at six weeks of age has reduced the prevalence of persistent HBV infection [6], the impact of HIV on HBV mother-to-child transmission (MTCT) in SSA is not well described. Moreover, little is known about the prevalence of persistent viral hepatitis in HIV-infected (HIV+) children.

About 1.96 million of 36.7 million HIV + individuals $(\sim 5.3 \%)$ in SSA are co-infected with HBV [10]. Of concern is the high prevalence of HBV e-antigen (HBeAg) in HIV + pregnant women [11]. In a recent Malawian study, $38.2 \%$ of $102 \mathrm{HIV} / \mathrm{HBV}$ co-infected women of childbearing age were $\mathrm{HBeAg}$ positive [12]. $\mathrm{HBeAg}$ prevalence rates of $18.9 \%(10 / 53)$ and $37.5 \%(6 / 16)$ have been reported in South Africa [13, 14]. HBeAg positivity is associated with higher HBV viral loads and increased risk of HBV MTCT [15]. In pregnancy, $\mathrm{HBeAg}$ positivity carries a $90 \%$ risk of HBV MTCT compared to $25 \%$ for HBeAg negative women [16]. Prevention of HIV MTCT (PMTCT) guidelines recommend routine HIV testing for all pregnant women with unknown HIV status. However, as HBV antenatal screening is not routinely performed in many parts of SSA, the extent of perinatal HBV transmission in the HIV era remains underinvestigated. Whilst there is some epidemiological data in blood donors and antenatal cohorts, there are few reports in children [17].

$\mathrm{HCV}$ prevalence is considered low in SSA [18], but little is known about HCV in pregnancy and in children, in particular in those who are HIV co-infected. This study aimed to establish the prevalence of HBV and HCV infection in infants of HIV + mothers in South Africa.

\section{Methods}

\section{Study design}

This was a retrospective study using residual samples from the P1041 trial through the International Maternal
Paediatric Adolescent AIDS Clinical Trial (IMPAACT) Group. P1041 was a multi-centre, Phase II-III randomized, double blind, placebo-controlled trial to determine the efficacy of isoniazid in preventing tuberculosis (TB) disease and latent $\mathrm{TB}$ infection among infants perinatally exposed to HIV [19]. From December 2004 to June 2008, 1354 infants born to HIV + mothers in South African sites including Cape Town, Durban, and Johannesburg, and Gaborone in Botswana were enrolled in the P1041 study. Among these 1354 infants, 548 were HIVinfected and 806 were HIV-uninfected. Collection of data and blood samples occurred at three time points: at study entry, which corresponded to approximately 12 weeks of age ("Week 0 " on study), at $\sim 24$ weeks of age ("Week 12" on study) and 60 weeks of age ("Week 48" on study). The HBV infection status of the mothers was unknown.

Available plasma and serum samples from "Week 48" from the South African sites were screened for active $\mathrm{HBV}$ and HCV infections. Samples collected at earlier time points (i.e. "Week 0" and "Week 12") from infants found HBsAg positive at "Week 48" were tested for active HBV infection, and attempts were made to trace all HBsAg positive infants and their mothers for serological and molecular follow-up testing. Universal HBV immunisation at 6,10 and 14 weeks of age was introduced in South Africa in 1995, preceding the P1041 trial by nine years.

\section{Serological screening}

Given the limited sample volumes available, serological testing was done at 1:10 dilution in normal human plasma, on the Abbott ARCHITECT i2000SR automated platform (Abbott Diagnostics, Delkenheim, Germany), following previous validation (data not shown).

Samples were tested for HBsAg, anti-HBs, anti-HBc (total) and anti-HCV using the ARCHITECT i2000SR system, according to manufacturer's instructions. HBsAg positive samples were tested for $\mathrm{HBeAg}$ and anti-HBe using the ARCHITECT HBeAg and anti-HBe chemiluminescent immunoassays. Anti-HBs titre $\geq 10 \mathrm{IU} / \mathrm{mL}$ is the accepted threshold for protective immunity against HBV. Samples with anti-HBs titres below $1 \mathrm{IU} / \mathrm{ml}$ were recorded anti-HBs negative. Samples with anti-HBs levels falling between $10 \mathrm{IU} / \mathrm{ml}$ and $100 \mathrm{IU} / \mathrm{ml}$, indicator low level of immune protection against $\mathrm{HBV}$, were also recorded.

\section{Quantification of HBV DNA}

Viral DNA was extracted from $200 \mu \mathrm{l}$ of serum samples using the QIAamp ${ }^{\circ}$ MinElute ${ }^{\circ}$ Virus Spin kit (QIAGEN, Hilden, Germany). Extracted HBV DNA was amplified and quantified, using a probe-based real-time PCR assay on the RotorGene ${ }^{\mathrm{Tm}} 6000$ (Corbett Life Sciences, 
Australia), at the following cycling conditions: initial denaturation for 15 minutes at $95^{\circ} \mathrm{C}$ followed by 45 cycles of $95{ }^{\circ} \mathrm{C}$ for 15 seconds and $60{ }^{\circ} \mathrm{C}$ for 60 seconds [20]. Sequences of the primers and probes used in the assay were as described by Garson et al. (2005) [20].

\section{Quantification of HCV RNA}

Viral nucleic acid extraction and quantification were performed using the $\mathrm{COBAS}^{\circ}$ AmpliPrep/COBAS ${ }^{\circ}$ TaqMan HCV Test (Roche Molecular Diagnostics, Almere, Netherlands), according to manufacturer's instructions.

\section{HBV DNA sequencing}

DNA positive samples underwent sequencing of the polymerase/surface and core genomic regions [21, 22]. Genomic sequences were submitted to the National Center for Biotechnology Information HBV Genotyping tool (http://hivdb.stanford.edu/HBV/HBVseq/development/ HBVseq.html) and to Geno2Pheno (http://hbv.geno2 pheno.org/index.php) for HBV genotyping and to detect immune escape and drug resistance mutants, respectively.

\section{Phylogenetic analysis}

The relationship between maternal and children viral sequences was inferred using a Maximum Likelihood phylogenetic tree constructed using a bootstrap of 1000 replicates in MEGA 7 [23]. Evolutionary distances between the query sequences were calculated using the General Time Reversible model [24].

\section{Results}

The study population comprised of 821 infants from Cape Town, Durban, and Johannesburg with plasma samples available from "Week 48". Baseline demographics and HIV clinical characteristics are outlined in Table 1.

\section{Active HBV infection screening}

Among screened samples, three samples were positive for HBsAg and HBV DNA (3/821, 0.4\%), of which two were from HIV + infants and the other from an HIV exposed uninfected infant, one each from Cape Town, Johannesburg, and Durban. Five samples were anti-HBc (total) reactive $(5 / 821,0.6 \%)$; of these, three were also HBsAg positive while the other two were HBsAg negative. Insufficient sample volume prevented $\mathrm{HBeAg}$ and anti-HBe testing (Table 2). Sequencing of the HBV polymerase/surface and core genomic regions showed subgenotype A1 strains. Sequence analysis revealed the M204I mutation in the reverse transcriptase domain of the polymerase gene in the Durban sample while the Cape Town sample harboured the double A1762T/ G1764A BCP mutation in the core gene. No HBV mutation was found in the Johannesburg sample.
Table 1 Participant demographics and HIV characteristics of study population ${ }^{\text {a }}$

\begin{tabular}{ll}
\hline Characteristics & $\begin{array}{l}\text { Study population } \\
\mathbf{N =} \mathbf{8 2 1}(\%)\end{array}$ \\
\hline Age (in weeks) & 62 \\
Mean & $49-64$ \\
Min - Max & \\
Sex (\%) & $398(48 \%)$ \\
Male & $423(52 \%)$ \\
Female & \\
HBV vaccination & $129(16 \%)$ \\
Yes & $692(84 \%)$ \\
Unknown & \\
HIV infection & \\
Yes & $315(38 \%)$ \\
No & $506(62 \%)$ \\
On ART at sample collection & \\
Yes & $259(82 \%)$ \\
No & $56(18 \%)$ \\
\hline
\end{tabular}

${ }^{a}$ Assessed as of date of sample collection at Study "Week 48"; ${ }^{\text {'ART: }}$ combination Antiretroviral Therapy, defined as being on at least 3 drugs in at least 2 classes

\section{Retrospective serological and molecular testing}

One HBsAg positive infant (Cape Town) had been immunised against $\mathrm{HBV}$, while there were no records of HBV immunisation for the Durban and Johannesburg HBsAg positive infants. Samples from earlier time points were retrieved for the Durban and Cape Town infants and were screened for active HBV infection. Sample volume was sufficient for serological and molecular screening for the "Week 0" Cape Town sample and molecular testing only for the "Week 0" and "Week 24" Durban samples. All three samples were HBV DNA positive. The "Week 0" Cape Town sample showed a similar serological profile to the "Week 48" sample from the same child and also had the double A1762T/G1764A BCP mutation. Insufficient sample volume precluded testing the Johannesburg infant.

\section{Follow-up}

Two HBsAg positive infants (Durban and Johannesburg) could not be traced, but the HBsAg positive infant from Cape Town was traced and reviewed seven years after the "Week 48" screening assessment, at 8 years of age. This child was HIV + and receiving stavudine (D4T), lamivudine (3TC) and lopinavir/ritonavir (LPV/r) while the mother was on 3TC, tenofovir (TDF) and LPV/r.

\section{Follow-up serological and molecular testing}

Samples from both mother and child were HBsAg positive, $\mathrm{HBeAg}$ negative/anti-HBe positive at follow up. 
Table 2 Serological and molecular results of HBV-infected children at screening and follow-up

\begin{tabular}{|c|c|c|c|c|c|c|c|c|c|}
\hline \multirow[t]{2}{*}{ Patient } & \multirow[t]{2}{*}{ Location } & \multirow[t]{2}{*}{ HBV vaccination } & \multirow[t]{2}{*}{ HIV Status } & \multicolumn{2}{|c|}{ Screening } & \multicolumn{4}{|c|}{ Prospective follow-up } \\
\hline & & & & HBsAg & HBV DNA log $10(\mathrm{IU} / \mathrm{ml})$ & $\mathrm{HBsAg}$ & $\mathrm{HBeAg}$ & Anti-HBe & HBV DNA (IU/ml) \\
\hline $\mathrm{C} 1^{\mathrm{a}}$ & CPT & Yes & + & + & 8.93 & + & - & + & UD \\
\hline $\mathrm{C} 2$ & Durban & No record & + & + & 5.17 & ND & ND & ND & ND \\
\hline C3 & $J H B$ & No record & - & + & 8.45 & ND & ND & ND & ND \\
\hline
\end{tabular}

a Therapy: D4T, 3TC \& KLT (at follow-up); Anti-HBe antibody to hepatitis B e antigen, C Child, CPT Cape Town, IU/m/ International Units per milliliter, HBeAg hepatitis $B$ e antigen, $H B s A g$ hepatitis B surface antigen, JHB Johannesburg, - Negative, + Positive, ND Not done, UD Undetectable

While the child sample had an undetectable HBV viral load, low level HBV DNA was detected in the maternal sample (HBV viral load $=19 \mathrm{IU} / \mathrm{ml}$ ). Owing to the low maternal viral load, only core sequencing was successful. A comparison of the maternal and the "Week 48" infant HBV core sequences showed similarity in protein/nucleotide sequences ( $99 \%$ homology). Both sequences harboured the double A1762T/G1764A BCP mutation. Phylogenetic analysis showed close clustering between the maternal and child sequences (Fig. 1).

\section{HBV immunity screening}

HBV immunity, demonstrated by the presence of antiHBs only, was assessed in all 821 samples. Seroprotective levels of anti-HBs $\geq 10 \mathrm{IU} / \mathrm{ml}$ were found in $745 / 821$ samples (90.7\%); of which 277 (37.2\%) had anti-HBs levels $<100 \mathrm{IU} / \mathrm{ml}$. The remaining $76(9.3 \%)$ samples had
anti-HBs levels $<10 \mathrm{IU} / \mathrm{ml}$; of which 14 samples $(1.7 \%)$ were anti-HBs negative $(<1 \mathrm{IU} / \mathrm{ml})$. Among the five anti-HBc (total) reactive samples, the two HBsAg negative samples had anti-HBs levels above $100 \mathrm{IU} / \mathrm{ml}$ while the three HBsAg positive samples had anti-HBs levels below $10 \mathrm{IU} / \mathrm{ml}$.

\section{HCV infection screening}

All 813 "Week 48" samples tested for anti-HCV were negative. However, 21 samples showed S/CO values $>0.10$; this was thought to be due to nonspecific reactivity. In order to address the possibility that antibody response may have been impaired and low, HCV RNA testing was undertaken on 16/21 samples with sufficient volume available, with negative results.

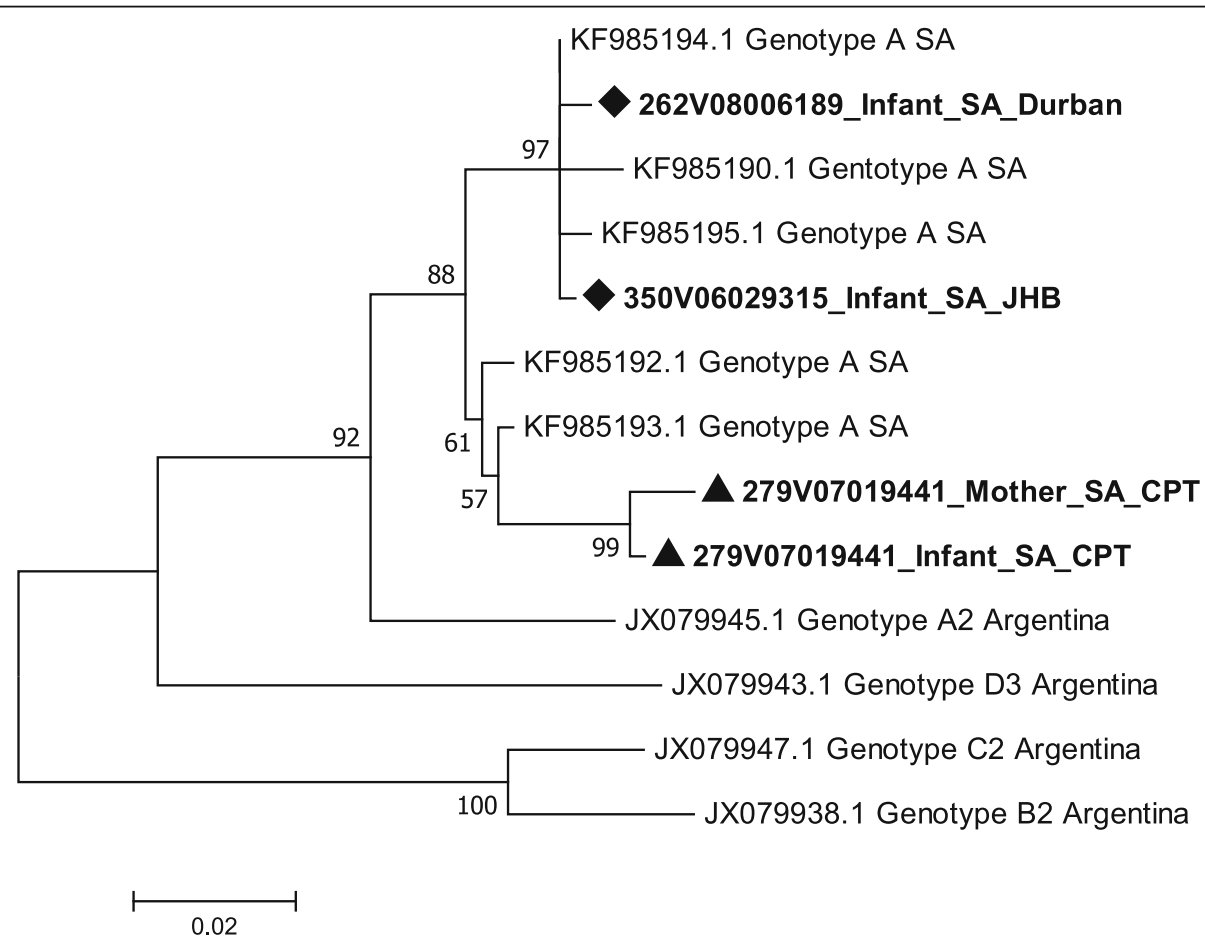

Fig. 1 Phylogenetic tree of HBV-infected infants and Cape Town mother based on the HBV core region. Sequences with accession numbers starting with JX and KF were downloaded from GenBank. The evolutionary history was inferred by using the Maximum Likelihood method based on the General Time Reversible model with 1000 bootstrap replicates. A discrete Gamma distribution [25] was used to model evolutionary rate differences among sites 


\section{Discussion}

In this cohort of infants born to $\mathrm{HIV}+$ mothers, three infant samples were HBsAg positive at "Week 48", giving a $0.4 \%$ prevalence of active infection (3/821). Testing for anti-HBc (total) showed that a further two infant samples $(2 / 821,0.2 \%)$ showed the presence of anti-HBc (total) levels greater than the assay's cut-off (>1 S/CO), suggesting past infection to $\mathrm{HBV}$. On repeat testing the Cape Town case revealed persistent HBV infection with a strain closely related to the maternal $\mathrm{HB}$ virus. This was despite infant HBV immunisation. The other two cases could not be traced.

In South Africa, HBV immunisation from six weeks of age was implemented in the mid-1990s as HBV transmission was thought to be predominantly horizontal [4, $26,27]$. This intervention led to a decrease in HBsAg prevalence rate from approximately $10 \%$ [28] to between $0 \%$ and $2.7 \%$ [29-33]. A pre- versus post-HBV immunization analysis of 1206 children aged 1 to 25 years in South Africa showed an HBsAg prevalence rate declining from $4.2-1.4 \%$, and prevalence of $\mathrm{HBV}$ immunity increasing from 13-57\% [6]. Although HBV immunisation was documented in only $16 \%(129 / 821)$ of our cohort, $90.6 \%(745 / 821)$ had protective anti-HBs levels, suggesting poor documentation rather than deficiencies in immunisation coverage.

Although the prevalence of $\mathrm{HBV}$ infection in childhood has declined, HBV perinatal transmission remains a concern. Delay in seroconversion to anti-HBe, reactivation of $\mathrm{HBe}$ antigenemia and sero-reversion to $\mathrm{HBsAg}$ positivity, indicative of increased $\mathrm{HBV}$ replication through HIV-induced immunosuppression, are well described in HIV + patients [34, 35]. High HBsAg and $\mathrm{HBeAg}$ prevalences with high $\mathrm{HBV}$ replication activity have been described in HIV + South African women [13]. Furthermore, a study from Soweto described four cases of perinatal transmission from $14 \mathrm{HIV}+$ mothers. Three of the four infants were born to $\mathrm{HBeAg}$ positive mothers with $\mathrm{HBV}$ viral load of $1.995 \mathrm{E}+8 \mathrm{IU} / \mathrm{ml}$, 6.309 IU/ml and $100 \mathrm{IU} / \mathrm{ml} \mathrm{HBV} \mathrm{DNA} \mathrm{[36].}$

The present study showed a HBsAg prevalence $(0.4 \%$, $3 / 820$ ) similar to that in $1000 \mathrm{HIV}$-exposed infants from the Western Cape's PMTCT program [37]. In both studies, HBV immunisation starting at six weeks of age failed to prevent all HBV MTCT.

It is well established that HBV immunisation at birth alone is effective in preventing HBV perinatal transmission from some HBV-infected women [38-40] but is only partially protective for infants born to mothers with high HBV viral loads [41]. Giving hepatitis B immunoglobulin (HBIG) together with HBV birth vaccine, active/passive immunisation further reduces the risk of HBV MTCT $[38,42,43]$, but is costly and not logistically possible in many resource-limited settings. Treating women in the third trimester of pregnancy with antiviral drugs such as lamivudine [44], tenofovir [45] or telbivudine [46] is effective in reducing HBV viral load and thus reducing the risk of transmission. Tenofovir and emtricitabine (or lamivudine) have been part of first-line antenatal antiretroviral therapy (ART) in SSA since 2010, so HIV-HBV co-infected pregnant women would have received anti-HBV therapy. However, HBV mono-infected pregnant women remain unidentified and untreated, leaving their infants at risk of acquiring HBV from their mothers.

The other interesting aspect of these results is to consider the $2 / 5$ anti- $\mathrm{HBc}$ (total) reactive samples, which may indicate exposure to HBV infection, but may also reflect residual maternal antibody.

No HCV infection was identified in this study. HCV prevalence is considered low in SSA $(<1 \%)$ [18]. However, there is little published data from paediatric cohorts in this region. Further work is required to confirm the findings of this study.

While this study adds to our understanding of HBV epidemiology in South African infants, there are limitations in the interpretation of these results. The absence of ART data on mothers prevented assessing the effect of maternal ART on the HBV infection risk to infants. However, during the study period, TDF and emtricitabine (FTC) were unavailable and only $\mathrm{HIV}+$ mothers with a CD4 + T-cell count below 200 per $\mathrm{mm}^{3}$ were eligible for lamivudine-containing ART, which would have reduced the risk of $\mathrm{HBV}$ transmission. Currently in South Africa all HIV + women have access to ART containing TDF and lamivudine or FTC. In the absence of HBV screening in pregnancy, the risk of replacing tenofovir to a second- or third-line ART may not be appreciated. Maternal HBV status would have allowed calculation of a definitive risk of perinatal transmission but was unavailable. Limited immunisation records compromised the interpretation of anti-HBs levels. Finally, as the samples were collected more than seven years ago from three different locations, loss to follow-up prevented further assessment of two of the HBsAg positive cases.

\section{Conclusions}

This study shows evidence of HBV infections in infants born to HIV + mothers. No HCV infection was detected in this large cohort of HIV-exposed infants in South Africa. In order to eliminate $\mathrm{HBV}$ MTCT, a combination of strategies including HBV screening, together with maternal antiviral therapy and most importantly HBV immunisation at the time of birth will be required. These strategies, although well described, require further SSA data to assess the cost effectiveness ultimately to eliminate this route of $\mathrm{HBV}$ infection. 


\section{Abbreviations}

3TC: Lamivudine; Anti-HBc (total): Total antibodies against hepatitis B core antigen; Anti-HBe: Antibodies against hepatitis B e antigen; AntiHBs: Antibodies against hepatitis B surface antigen; Anti-HCV: Antibodies against hepatitis $C$ virus; ART: Antiretroviral therapy; BCP: Basal Core Promoter; CD4 + T-cell: Type CD4 + T cell; D4T: Stavudine;

DNA: Deoxyribonucleic acid; FTC: Emtricitabine; HBeAg: Hepatitis B e antigen; HBsAg: Hepatitis B surface antigen; HBV: Hepatitis B infection; HCV: Hepatitis C virus; HIV: Human Immunodeficiency Virus; LPV/r: Lopinavir/ritonavir; MTCT: Mother-to-child transmission; PMTCT: Prevention of mother-to-child transmission; RNA: Ribonucleic acid; SSA: Sub-Sahara Africa; TB: Tuberculosis; TDF: Tenofovir Disoproxil Fumarate; VL: Viral load; WHO: World Health Organization

\section{Acknowledgements}

Our sincere gratitude goes to the study participants and the IMPAACT group for allowing access to these samples and the study team for all their efforts throughout this study and in the writing of this manuscript.

\section{Authors' contributions}

Study conceptualization and design: MFC, AV, and MIA. Funding acquisition: MFC and MIA. Methodology: CTT, RT, WP, and MIA. Validation: CTT, RT, and MIA. Resources: RT, AV, RB, LH, LA, GM, CM, MIA. Project administration: CTT, MFC, and MIA. Data collection and investigation: CTT. Data analysis and interpretation: CTT, RT, EN, WP, and MIA. Visualization: CTT. Supervision: WP and MIA. Manuscript original drafting: CTT, MFC, WP, and MIA. Critical review and manuscript revision: CTT, MFC, EN, RT, WP, AV, RB, LH, LA, GM, CM, and MIA. All authors read and approved the final version of the manuscript.

\section{Funding}

The study was financially sponsored by the National Health Laboratory Service Research Trust, the Poliomyelitis Research Foundation, and the Harry Crossley Foundation to support materials, reagents, and laboratory testing. Overall financial support for the International Maternal Pediatric Adolescent AIDS Clinical Trials Network (IMPAACT) was provided by the National Institute of Allergy and Infectious Diseases (NIAID) with co-funding from the Eunice Kennedy Shriver National Institute of Child Health and Human Development (NICHD) and the National Institute of Mental Health (NIMH), all components of the National Institutes of Health $(\mathrm{NIH})$, under Award Numbers UM1AI068632 (IMPAACT LOC), UM1AI068616 (IMPAACT SDMC) and UM1Al106716 (IMPAACT LC), and by NICHD contract number HHSN275201800001I. The funders had no participation in the design, data collection and analysis, interpretation of the results of this study and in writing of the manuscript.

\section{Availability of data and materials}

The datasets during and/or analysed during the current study are available from the corresponding author on reasonable request.

\section{Ethics approval and consent to participate}

Ethics approval was received from the Health Research Ethics Committees of Stellenbosch University (N10/04/115) and the University of Witwatersrand (020109), and the Biomedical Research Ethics Committee of the University of Kwazulu-Natal (T118/05). Mothers included in the original P1041 study also provided informed written consent, prior inclusion, for testing of other infections that affect people with HIV (including hepatitis viruses). Written informed consent was obtained from parents or legal guardians for babies and children included in the study.

\section{Consent for publication}

Not applicable.

\section{Conpeting interests}

The authors declare that they have no financial or personal interest(s) which may have inappropriately influenced them during the conduct of this research study and in writing this article.

\section{Author details}

${ }^{1}$ Division of Medical Virology, Department of Pathology, Faculty of Medicine and Health Sciences, Stellenbosch University, Cape Town, South Africa. ${ }^{2}$ Department of Paediatrics \& Child Health, Faculty of Medicine and Health
Sciences, FAM-CRU, Stellenbosch University, Cape Town, South Africa. ${ }^{3}$ Department of Paediatrics \& Child Health, Faculty of Medicine and Health Sciences, Stellenbosch University, Cape Town, South Africa. ${ }^{4}$ Blood Borne Viruses Unit, Virus Reference Department, Public Health England, London, UK. ${ }^{5}$ Perinatal HIV Research Unit, University of the Witwatersrand, Johannesburg, South Africa. ${ }^{6}$ Department of Paediatrics, Nelson R. Mandela School of Medicine, University of KwaZulu Natal, Durban, South Africa. ${ }^{7}$ Frontier Science and Technology Research Foundation, New York, USA. ${ }^{8}$ Center for Biostatistics in AIDS Research, Harvard T.H. Chan School of Public Health, Boston, Massachusetts, USA. 'Department of Paediatrics, School of Medicine, University of Miami Miller, Miami, USA. ${ }^{10}$ Department of Microbiology and Infectious Diseases, Oxford University Hospitals NHS Foundation Trust, Oxford, UK.

Received: 6 July 2020 Accepted: 17 December 2020 Published online: 24 December 2020

\section{References}

1. Lozano R, Naghavi M, Foreman K, Lim S, Shibuya K, Aboyans V, et al. Global and regional mortality from 235 causes of death for 20 age groups in 1990 and 2010: a systematic analysis for the Global Burden of Disease Study 2010. Lancet. 2013;380:2095-128. https://doi.org/10.1016/S01406736(12)61728-0.

2. World Health Organization. Hepatitis B. 2019. http://www.who.int/ mediacentre/factsheets/fs204/en/. (Accessed 09 Feb 2018).

3. World Health Organization. Hepatitis C. 2019. http://www.who.int/ mediacentre/factsheets/fs164/en/. (Accessed 09 Feb 2018).

4. Prozesky OW, Szmuness W, Stevens CE, Kew MC, Harley EJ, Hoyland JA, et al. Baseline epidemiological studies for a hepatitis B vaccine trial in Kangwane. S Afr Med J. 1983;64:891-3.

5. Botha JF, Dusheiko GM, Ritchie MJJ, Mouton HW, Kew MC. Hepatitis B virus carrier state in black children in Ovamboland: role of perinatal and horizontal infection. Lancet. 1984;323:1210-2. https://doi.org/10.1016/S01406736(84)91694-5.

6. Amponsah-Dacosta E, Lebelo RL, Rakgole JN, Burnett RJ, Selabe SG, Mphahlele MJ. Evidence for a change in the epidemiology of hepatitis B virus infection after nearly two decades of universal hepatitis $B$ vaccination in South Africa. J Med Virol. 2014;86:918-24. https://doi.org/10.1002/jmv. 23910.

7. Keane E, Funk AL, Shimakawa Y. Systematic review with meta-analysis: the risk of mother-to-child transmission of hepatitis $B$ virus infection in subSaharan Africa. Aliment Pharmacol Ther. 2016;44:1005-17. https://doi.org/10 1111/apt.13795.

8. World Health Organization. Hepatitis B vaccines: WHO position paper - July 2017. Wkly Epidemiol Rec. 2017;27:369-92.

9. Woodring J, Pastore R, Brink A, Ishikawa N, Takashima Y, Tohme RA Progress Toward Hepatitis B Control and Elimination of Mother-to-Child Transmission of Hepatitis B Virus - Western Pacific Region, 2005-2017. Morb Mortal Wkly Rep. 2019;68:195-200. 10.15585/mmwr.mm6808a2.

10. World Health Organization. Global hepatitis report, 2017. 2018 https://apps. who.int/iris/bitstream/handle/10665/255016/9789241565455-eng. pdf?sequence=1. (Accessed 22 Mar 2018).

11. Andersson MI, Maponga TG, ljaz S, Theron G, Preiser W, Tedder RS. High HBV viral loads in HIV-infected pregnant women at a tertiary hospital, South Africa. J Acquir Immune Defic Syndr. 2012;60:e111-2. https://doi.org/10. 1097/QAl.0b013e31825aeee7.

12. Chasela CS, Kourtis AP, Wall P, Drobeniuc J, King CC, Thai H, et al. Hepatitis $B$ virus infection among HIV-infected pregnant women in Malawi and transmission to infants. J Hepatol. 2014;60:508-14. https://doi.org/10.1016/j. jhep.2013.10.029.

13. Andersson M, Maponga T, ljaz S, Barnes J, Theron GB, Meredith SA, et al. The epidemiology of hepatitis B virus infection in HIV-infected and HIVuninfected pregnant women in the Western Cape, South Africa. Vaccine. 2013;31:5579-84. https://doi.org/10.1016/j.vaccine.2013.08.028

14. Thumbiran NV, Moodley D, Parboosing R, Moodley P. Hepatitis B and HIV co-infection in pregnant women: Indication for routine antenatal hepatitis $B$ virus screening in a high HIV prevalence setting. S Afr Med J. 2014;104:3079. https://doi.org/10.7196/SAMJ.7299.

15. Burnett RJ, Ngobeni JM, François G, Hoosen AA, Leroux-Roels G, Meheus A, et al. Increased exposure to hepatitis B virus infection in HIV-positive South 
African antenatal women. Int J STD AIDS. 2007;18:152-6. https://doi.org/10 1258/095646207780132523.

16. Umar M, Hamama-Tul-Bushra, Umar S, Khan HA. HBV Perinatal Transmission. Int J Hepatol. 2013;2013:875791-7. https://doi.org/10.1155/2013/875791.

17. Mora N, Adams WH, Kliethermes S, Dugas L, Balasubramanian N, Sandhu J, et al. A synthesis of hepatitis $C$ prevalence estimates in sub-Saharan Africa: 2000-2013. BMC Infect Dis. 2016;16:283. https://doi.org/10.1186/s12879-0161584-1.

18. Karoney MJ, Siika AM. Hepatitis $\mathrm{C}$ virus (HCV) infection in Africa: a review. Pan Afr Med J. 2013;14:44. https://doi.org/10.11604/pami.2013.14.44.2199.

19. Madhi SA, Nachman S, Violari A, Kim S, Cotton MF, Bobat R, et al. Primary isoniazid prophylaxis against tuberculosis in HIV-exposed children. N Engl J Med. 2011;365:21-31. https://doi.org/10.1056/NEJMoa1011214.

20. Garson JA, Grant PR, Ayliffe U, Ferns RB, Tedder RS. Real-Time PCR. Quantitation of Hepatitis B Virus DNA using Automated Sample Preparation and Murine Cytomegalovirus Internal Control. J Virol Methods. 2005;126: 207-13. https://doi.org/10.1016/j.jviromet.2005.03.001.

21. Dervisevic S, ljaz S, Chaudry S, Tedder RS. Non-A hepatitis B virus genotypes in antenatal clinics, United Kingdom. Emerg Infect Diseases. 2007;13:168993. https://doi.org/10.3201/eid1311.070578.

22. Public Health England. Recommended Protocol for HBV genotyping and for antiviral resistance analysis. 2007. https:/www.gov.uk/government/uploads/ system/uploads/attachment_data/file/342414/cfi_vrd

PolHBsAgRecommendationsFINAL_HBV_protocol.pdf. (Accessed 09 Feb 2018).

23. Tamura K, Stecher G, Peterson D, Filipski A, Kumar S. MEGA6: Molecular Evolutionary Genetics Analysis version 6.0. Mol Biol Evol. 2013:30:2725-9. https://doi.org/10.1093/molbev/mst197.

24. Tavaré S. Some probabilistic and statistical problems in the analysis of DNA sequences. In: Miura RM, editor. Some Mathematical Questions in Biology DNA Sequence Analysis. Providence: Amer Math Soc; 1986. p. 57-86.

25. Yang Z. Maximum likelihood phylogenetic estimation from DNA sequences with variable rates over sites: approximate methods. J Mol Evol. 1994;39: 306-14. https://doi.org/10.1007/BF00160154.

26. Vos GH, Rose EF, Marimuthu T. Hepatitis B, Antigen. and Antibodies in Rural and Urban Southern African Blacks. S Afr Med J. 1980;57:868-70.

27. Abdool Karim SS, Coovadia HM, Windsor IM, Thejpal R, Van Den Ende JA, Fouche A. The Prevalence and Transmission of Hepatitis B Virus Infection in Urban, Rural and Institutionalized Black Children of Natal/KwaZulu, South Africa. Int J Epidemiol. 1988;17:168-73. https://doi.org/10.1093/ije/17.1.168.

28. Kew M, Miller G, Stevenson C, Macnab GM, Bersohn I. The Prevalence of Virus-B Hepatitis South African Blacks. S Afr Med J. 1974;48:1837-8.

29. Tsebe KV, Burnett RJ, Hlungwani NP, Sibara MM, Venter PA, Mphahlele MJ. The first five years of universal hepatitis B vaccination in South Africa: evidence for elimination of HBsAg carriage in under 5-year-olds. Vaccine. 2001;19:3919-26. https://doi.org/10.1016/S0264-410X(01)00120-7.

30. Hino K, Katoh Y, Vardas E, Sim J, Okita K, Carman WF. The effect of introduction of universal childhood hepatitis B immunization in South Africa on the prevalence of serologically negative hepatitis B virus infection and the selection of immune escape variants. Vaccine. 2001;19:3912-18. https:// doi.org/10.1016/S0264-410X(01)00121-9.

31. Mphahlele M, Francois G, Kew M, Van Damme P, Hoosen AA, Meheus A. Epidemiology and Control of Hepatitis B: Implications for Eastern and Southern Africa. South Afr J Epidemiol Infect. 2002;17:12-7.

32. Schoub BD, Matai U, Singh B, Blackburn NK, Levin JB. Universal immunization of infants with low doses of a low-cost, plasma-derived hepatitis B vaccine in South Africa. Bull World Health Organ. 2002;80:277-81,

33. Simani OE, Leroux-Roels $G$, François $G$, Burnett RJ, Meheus A, Mphahlele MJ. Reduced detection and levels of protective antibodies to hepatitis $B$ vaccine in under 2-year-old HIV positive South African children at a paediatric outpatient clinic. Vaccine. 2009;27:146-51. https://doi.org/10.1016/j.vaccine. 2008.10.004

34. Thio CL. Hepatitis B and human immunodeficiency virus coinfection. Hepatology. 2009:49:138-45. https://doi.org/10.1002/hep.22883.

35. Paganelli M, Stephenne X, Sokal EM. Chronic hepatitis B in children and adolescents. J Hepatol. 2012;57:885-96. https://doi.org/10.1016/j.jhep.2012. 03.036 .

36. Hoffmann CJ, Mashabela F, Cohn S, Hoffmann JD, Lala S, Martinson NA et al. Maternal hepatitis $B$ and infant infection among pregnant women living with HIV in South Africa. J Int AIDS Soc. 2014;17:18871. https://doi.org/ 10.7448/IAS.17.1.18871.
37. Chotun N, Nel E, Cotton MF, Andersson MI. Hepatitis B virus infection in HIV-exposed infants in the Western Cape, South Africa. Vaccine. 2015;33: 4618-22. https://doi.org/10.1016/j.vaccine.2015.06.076.

38. Lee C, Gong Y, Brok J, Boxall EH, Gluud C. Hepatitis B immunisation for newborn infants of hepatitis B surface antigen-positive mothers. Evid Based Child Health. 2006;2:67-155.

39. Poovorawan Y, Chongsrisawat V, Theamboonlers A, Srinivasa K, Hutagalung $Y$, Bock HL, et al. Long-term benefit of hepatitis B vaccination among children in Thailand with transient hepatitis B virus infection who were born to hepatitis B surface antigen-positive mothers. J Infect Dis. 2009;200:33-8. https://doi.org/10.1086/599331.

40. Evans AA, Cohen C, Huang P, Qian L, London WT, Block JM, et al. Prevention of perinatal hepatitis B transmission in Haimen City, China: Results of a community public health initiative. Vaccine. 2015;33:3010-15. https://doi.org/10.1016/j.vaccine.2015.01.054

41. Sellier P, Maylin S, Amarsy R, Mazeron MC, Larrouy L, Haïm-Boukobza S, et al. Untreated highly viraemic pregnant women from Asia or sub-Saharan Africa often transmit hepatitis B virus despite serovaccination to newborns. Liver Int. 2015;35:409-16. https://doi.org/10.1111/liv.12561.

42. Chakvetadze C, Roussin C, Roux J, Mallet V, Petinelli ME, Pol S. Efficacy of hepatitis B sero-vaccination in newborns of African $\mathrm{HBsAg}$ positive mothers. Vaccine. 2011;29:2846-9. https://doi.org/10.1016/j.vaccine.2011.01.101.

43. Yahyapour Y, Karimi M, Molaei HR, Khoddami E, Mahmoudi M. Activepassive Immunization Effectiveness Against Hepatitis B Virus in Children Born to HBsAg Positive Mothers in Amol, North of Iran. Oman Med J. 2011; 26:399-403. https://doi.org/10.5001/omj.2011.103.

44. Köse $\mathrm{S}$, Türken M, Devrim I, Taner C. Efficacy and safety of lamivudine treatment in late pregnancy with high HBV DNA: a perspective for mother and infants. J Infect Dev Ctries. 2011;5:303-6. https://doi.org/10.3855/jidc. 1398.

45. Greenup AJ, Tan PK, Nguyen V, Glass A, Davison S, Chatterjee U, et al. Efficacy and safety of tenofovir disoproxil fumarate in pregnancy to prevent perinatal transmission of hepatitis B virus. J Hepatol. 2014;61:502-7. https:// doi.org/10.1016/j.jhep.2014.04.038.

46. Han G, Jiang H, Yue X, Ding Y, Wang CM, Wang GJ, et al. Efficacy and safety of telbivudine treatment: an open-label, prospective study in pregnant women for the prevention of perinatal transmission of hepatitis B virus infection. J Viral Hepat. 2015;22:754-62. https://doi.org/10.1111/jvh.12379.

\section{Publisher's Note}

Springer Nature remains neutral with regard to jurisdictional claims in published maps and institutional affiliations.

Ready to submit your research? Choose BMC and benefit from:

- fast, convenient online submission

- thorough peer review by experienced researchers in your field

- rapid publication on acceptance

- support for research data, including large and complex data types

- gold Open Access which fosters wider collaboration and increased citations

- maximum visibility for your research: over $100 \mathrm{M}$ website views per year

At BMC, research is always in progress.

Learn more biomedcentral.com/submissions 